\title{
Forum
}

\section{Managing Complex Problems in Rangeland Ecosystems}

\author{
Chad S. Boyd ${ }^{1}$ and Tony J. Svejcar ${ }^{2}$ \\ Authors are ${ }^{1}$ Rangeland Scientist and ${ }^{2}$ Research Leader, USDA-Agricultural Research Service, Eastern Oregon Agricultural Research Center, 67826-A, \\ Hwy 205, Burns, OR 97720, USA.
}

\begin{abstract}
Management of rangelands, and natural resources in general, has become increasingly complex. There is an atmosphere of increasing expectations for conservation efforts associated with a variety of issues from water quality to endangered species. We argue that many current issues are complex by their nature, which influences how we approach them. We define a complex problem as one that varies in time and space. In other words, one answer may not be correct for all sites or during all years. For simple problems a generalized answer may be sufficient, and even for complex problems, general rules provide a good starting point. However, we suggest that it is important to distinguish between simple and complex problems. Several key obstacles emerge when considering complex natural resource problems, namely, 1) no single entity can handle all aspects of the problem and 2) significant knowledge gaps exist and will continue to exist into the future. We suggest that overcoming these obstacles will benefit from 1) a framework for effective partnerships and 2) a mechanism for continuous learning. Managing complex problems will require some combination of the following: 1) a process-based understanding of the problem (i.e., what causes variation in time and space), 2) adaptive management, and 3) effective coordination of research and management. There are many examples of organizations applying portions of these approaches to complex problems; however, it seems that in many cases the process has simply evolved in that direction rather than being a planned strategy. We suggest that as a profession we need to have a discussion about the nature of the problems we are addressing and how researchers and managers can jointly address these problems.
\end{abstract}

\section{Resumen}

El manejo de pastizales naturales, y de los recursos naturales en general, se ha tornado cada vez más complejo. Existe un ambiente de expectativas crecientes en cuanto a los esfuerzos de conservación asociados con una variedad de temáticas que abarcan desde la calidad del agua hasta especies en peligro de extinción. Sostenemos que mucha de la problemática actual es intrínsecamente compleja, y que dicha complejidad incide en el modo en que abordamos esta problemática. Definimos un problema complejo como aquel que varía a través del tiempo y el espacio. Es decir que una respuesta podría no ser la solución correcta para todos los sitios ni para todos los años. Las respuestas generales son casi siempre suficientes para la resolución de problemas sencillos, y aún el caso de problemas complejos, las reglas generales constituyen un buen punto de partida. No obstante, sugerimos que es importante distinguir entre problemas sencillos y complejos. Existen varios obstáculos clave que emergen cuando se consideran problemas complejos asociados con los recursos naturales: 1) ninguna entidad por si sola puede abordar todos los aspectos de un problema y 2) existen vacíos de conocimiento considerables que continuarán existiendo en el futuro. Proponemos que sortear estos obstáculos producirá como beneficios: 1) un marco para la generación de asociaciones efectivas y 2) un mecanismo para el aprendizaje continuo. El manejo de problemas complejos requerirá una combinación de los siguientes factores: 1) una comprensión del problema basado en procesos (es decir, qué es lo que genera la variación en el tiempo y el espacio), 2) manejo adaptativo, y 3) coordinación efectiva entre actividades de investigación y manejo. Existen muchos ejemplos de organizaciones que aplican porciones de estos enfoques para la resolución de problemas complejos, sin embargo, en muchos casos parecería que el proceso ha evolucionado en esta dirección sin mediar una estrategia planificada. Proponemos que como profesión debemos tener una discusión sobre la naturaleza de los problemas que estamos abordando y sobre el modo en que los sectores de investigación y manejo pueden abordar dichos problemas conjuntamente.

Key Words: adaptive management, conservation partnerships, decision tools, ecological complexity, ecosystem management, knowledge distillation, process-based ecology, windows of management opportunity

\section{INTRODUCTION}

In the 1930s, rangelands of the western United States were an ecological disaster. A 1936 report from the Secretary of

Correspondence: Chad S. Boyd, USDA-Agricultural Research Service, Eastern Oregon Agricultural Research Center, 67826-A, Hwy 205, Burns, OR 97720, USA. Email: chad.boyd@ oregonstate.edu

Manuscript received 24 September 2008; manuscript accepted 23 June 2009.
Agriculture to Congress (Anonymous 1936) stated that 95\% of the rangeland in public domain was in declining condition and called for "action of greatest immediate urgency and importance" to halt the degradation. The report went on to suggest that all rangelands be placed under management that would "stop depletion" and recommended "drastic reductions of stock on overgrazed ranges" given that stocking rates at the time were nearly double the estimated carrying capacity of western ranges. Passage of the Taylor Grazing Act set up 
grazing districts and gave authority to the Secretary of the Interior to "stop injury to the public grazing lands by preventing overgrazing." Although ecologists and historians will continue to parse the long-term effectiveness of the Taylor Grazing Act, the bottom line is that the act precipitated a decrease in livestock numbers that continues to this day; and few would argue the point that public rangelands are in demonstrably better condition today than the 1930s. The Taylor Grazing Act embodies a heroic approach to addressing large-scale natural resources problems that has many parallels in the conservation history of the United States. Whether it be Theodore Roosevelt's expansionistic vision of the National Forest System (Trefethen 1985), or the Endangered Species Act (Mann and Plummer 1996), the United States is a country that has gravitated toward broad, sweeping programs for managing our natural resources.

The commonality in all of the preceding efforts is that they can be viewed as responses to easily defined threats (e.g., overgrazing, overharvest, point source pollution, and pesticide impacts on the bald eagle). We are still trying to use this model in various forms to effectively deal with resource issues on rangelands. However, the problems most often confronting managers and administrators today are more diffuse by comparison, often resulting from multiple causative factors that vary over time and space. These problems are fundamentally different from those of previous generations and may not be solved by big, expensive programmatic approaches (i.e., topdown efforts emphasizing a static body of knowledge). In fact, such tactics can actually make some problems worse. We argue instead for a management approach that embraces the complexities of important rangeland issues and a scienceoriented framework that unites an understanding of processbased ecology with management opportunities in space and time. Specifically, our objectives are to 1) differentiate simple and complex problems, 2) examine the importance of evolutionary (i.e., continual) knowledge acquisition in addressing complex problems, 3) discuss barriers to adaptive management of complex problems, and 4) propose an alternative to traditional adaptive management that involves strengthening the relationship between science and management across years and sites. Many of our examples will be from the sagebrush steppe, but the principles apply to most rangeland settings where multiple uses or a variety of stakeholders are present.

\section{SIMPLE AND COMPLEX PROBLEMS}

Since its formalized inception, the field of rangeland science and management has sought to generalize properties of ecological systems in ways that have management utility over both time and space. Examples of such generalizations specific to grazing include the idea of "take half/leave half," leave four inches of stubble height in riparian areas, wait two years after fire to graze, use mineral placement to alter grazing distribution, and so on. This concept of "idealized knowledge" can work, and work well, when problems are simple; "simple" problems are defined as those in which the input variables and the relationships between those variables are, for all practical purposes, constant. Under these circumstances, management actions usually have predictable outcomes, and some of these "predictable outcomes" ultimately become general rules for management that can be incorporated into larger-scale programs. However, these generalizations become difficult to apply when input variables are not constant and/or when the relationships between those variables are dynamic across space and time. In such cases, the problem itself has graduated from a simple to a "complex" problem, and the appropriate solution(s) to the problem will vary over both time and space. Using watershed terminology, complex problems would be "nonpoint source," as opposed to comparatively simplistic "pointsource" problems. We submit that many of the simple problems have been solved and that the majority of challenges currently faced by rangeland managers are complex. We acknowledge that most natural resource professionals inherently know they are dealing with complex problems, but we all tend to be constrained by both our approaches and organizational barriers.

Transition from a simple to complex problem can be triggered by an increase in the scale of the problem (either spatial and/or temporal) or by our desire to understand a simple problem at a more mechanistic level. Whichever the case, addressing complex problems requires a different way of thinking about management and its relationship to the ecology of the resource. At this level, human conventions based on collective experience (e.g., take half/leave half) are no longer sufficient and must be replaced by a process-based (or mechanistic) understanding of the biology of the underlying problem. This knowledge in turn serves as a biological foundation for defining windows of management opportunity.

A good example of a complex problem would be the impacts of fire on the quality of sage-grouse (Centrocercus urophasianus) habitat in the Great Basin. This issue can be viewed as a complex problem on at least two conceptual levels. First, from a biological standpoint, fire impacts on habitat will vary over both space (based on scale of the burn, quality and composition of adjacent habitats, subspecies of sagebrush, moisture regime, pre-burn plant species composition, grazing regime, etc.) and time (due to dynamic plant species composition, changes in grazing regime, time since last fire, drought, the influence of atmospheric $\mathrm{CO}_{2}$ on plant species performance, etc.). Second, the decisions regarding management of sage-grouse habitat are set within a dynamic societal context, and these contexts translate into different management emphases and attitudes over time. Such factors can combine to make some rangeland management issues seem intractable and argue for an approach that embraces the dynamic nature of rangeland environments.

\section{INCREASING EXPECTATIONS}

The complexity of rangeland conservation itself is set within an atmosphere of increasing expectations from our conservation efforts. Recently the National Ecological Assessment Team (2006) identified the primary drivers of changing expectations as 1) advances in conservation theory, 2) emerging geospatial technology, and 3) increasing accountability for management efforts; to this list we add the "democratization" of decisions (Whaley 1993). Changes in expectations resulting from these catalysts include moving from site-scale conservation to a focus 
on producing sustainable populations and landscapes, from activity-based conservation (where more of everything is better) to science-based activities with measurable objectives (National Ecological Assessment Team 2006), and from top-down administrative decision making to public/interest group involvement at multiple scales. These increasing expectations relate less to any one taxonomic group or habitat type, and more to a general trend in natural resources conservation. The reality is that most managers and conservationists are embarking on a journey to manage complex problems at large spatial scales, and the question is, how can we collectively discuss this journey and develop a road map for success?

\section{ADAPTIVE MANAGEMENT}

The greatest enemy of knowledge is not ignorance ... it is the illusion of knowledge.

Stephen Hawking

One way to start this journey is by taking a page from Jim Collins's book From Good to Great: Why Some Companies Make the Leap ... and Others Don't (Collins 2001). In this book Collins searches for differences between good companies (those that temporarily beat the market baseline for stock returns) and great companies (those companies that maintained this level of performance for 15 years). One of the attributes common to all of the "great" companies was their ability and willingness to "face the brutal facts" of their business enterprise. If we apply that idea to attacking complex problems on rangeland, at least two brutal facts emerge: 1) no single conservation entity can handle all aspects of the task and 2) significant knowledge gaps exist, and will continue to exist, because of the complex nature of the problems (Thompson et al. 2001).

Adaptive management (Fig. 1) can be an effective approach to dealing with complex problems. The idea of adaptive management is not new (Holling 1978; Schreiber et al. 2004), and there is published information on the practical application of the concept (e.g., Reever-Morghan et al. 2006). As defined here, adaptive management is a model that uses a process of planning, doing, and learning to iteratively improve our knowledge of the ecology of the system, and allows us to evaluate both the success of management practices, as well as the validity of assumptions underlying management direction. In this model (National Ecological Assessment Team 2006; Fig. 1), biological planning is used to identify and prioritize conservation needs, set objectives, and develop working models that link management actions to biological processes. This information serves as the basis for a spatially targeted conservation design. Mechanisms for conservation delivery are then put together based on science and experience/intuition with both the natural and social systems in play. Follow-up monitoring provides a reference for gauging the success of conservation planning and delivery. Research is primarily centered on testing the assumptions underlying biological planning and conservation design. This process results in an increased understanding of the ecology and management of the system of interest, and that increased understanding can be plugged back into the planning and design elements. The important point here is that an approach that embraces

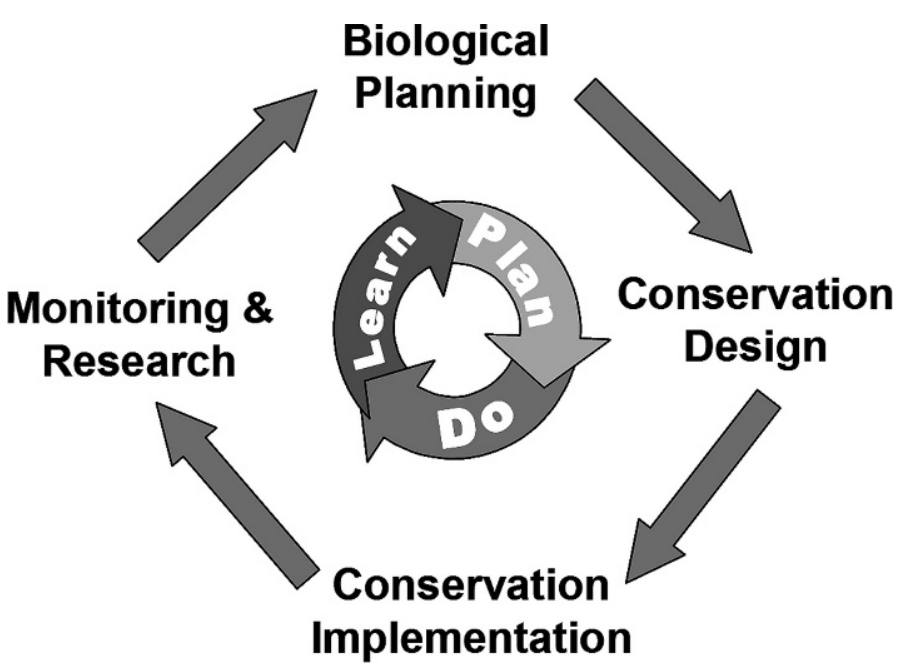

Figure 1. Adaptive management is generally framed in some version of this figure. In this case we used a modified version of the adaptive conservation model developed by the National Ecological Assessment Team (2006). Adaptive conservation begins with building models that biologically link potential management actions with desired changes in the ecological system (biological planning). This information is then translated into a spatially explicit conservation design that indicates what will be done and where it will occur on the landscape. Following implementation, research and monitoring are used to document management impacts and assess the validity of assumptions made in the planning process. This process links different conservation elements into an iterative cycle of planning, doing, and learning that allows for management in the face of uncertainty.

adaptive management helps us to overcome both of the previously mentioned "brutal facts" by 1) laying out a framework for effective partnerships (i.e., the schematic in Fig. 1 can be used as a planning tool to organize what roles need to be played and who will play them) and 2) using a planning, doing, and learning model to create the feedback loop necessary to manage in an uncertain environment.

\section{ADAPTIVE MANAGEMENT CHALLENGES}

Although adaptive management holds promise as a useful approach for dealing with complex conservation issues, significant challenges are associated with its implementation. Our treatment below is not meant to be a comprehensive listing of such challenges, but instead offers insights into some of the basal obstacles affecting the ability of managers to address complex problems.

\section{Programmatic Culture}

At present, natural resources conservation agencies often compartmentalize their various functions into discrete programs. This can work well from an administrative standpoint, but does not necessarily lend itself to adaptive management. Under the programmatic model, a body of knowledge is synthesized into what we believe is true (i.e., the "state of our knowledge"), and that "truth" is then translated into programmatic initiatives and objectives for those initiatives. Once started, however, this model may not contain mechanisms for 
improving knowledge over time. In other words, it treats knowledge acquisition as a point-in-time event, not the evolutionary/adaptive learning process that is required to manage complex problems. Reliance on point-in-time knowledge can in turn lead to dangerous overgeneralizations and continuance of marginally effective management practices.

Over time these generalizations and practices become habits, and the habits, in turn, coalesce into the fabric of the overall management program, effectively creating a "culture" of ideas and ways of doing business that give identity and direction to the program. Consider the issue of post-fire rehabilitation. In a given year rangeland managers may spend tens of millions of dollars seeding (i.e., "rehabilitating") perennial grasses on semiarid western rangeland following wildfire (Knutson et al. 2009), and these expenditures, in and of themselves, can be viewed as a success under the programmatic model. However, the biological reality is that successful germination and establishment of perennial plants following post-fire seeding can be extremely low (Lysne and Pellant 2004), particularly with native species and at lower elevations (Hull 1974; Richards et al. 1998). The extent of biological success of these rehabilitation treatments is unknown at present because outcomes are reported primarily in terms of the number of projects, number of acres treated, and cost (i.e., "implementation monitoring"); not in terms of biological success (i.e., "effectiveness monitoring"; see Bureau of Land Management Public Land Statistics, www.blm.gov/nhp/browse.htm).

In other words, there is a separation between biological and programmatic success. A simple litmus test for this disconnect is to ask the question: "Is it possible to simultaneously achieve biological failure and programmatic success?" If the answer is yes, there is a problem; and that problem stems from the fact that programmatic outcomes have become the management objectives as opposed to a more appropriate focus on biological outcomes.

In response to problems associated with range rehabilitation, the Bureau of Land Management has begun effectiveness monitoring of rehabilitation projects (Government Accountability Office 2006). However, this monitoring will yield little in the way of valuable insights in the absence of an adaptive framework that emphasizes the use of scientific controls. Unless adequate controls (e.g., randomly selected areas that are left unseeded) are included in the initial seeding efforts, separating the effectiveness of rehabilitation practices from recovery that would have occurred in the absence of such practices (i.e., "natural" recovery) will be impossible (Eiswerth and Shonkwiler 2006). The work of Pyke et al. (2003) suggests that nearly two-thirds of native species on rehabilitated Great Basin rangeland were the product of natural recovery, not rehabilitation treatment.

Employing adaptive management will require a change in culture for many programmatically oriented organizations. Initial progress in doing so will be predicated on acceptance of the idea that point-in-time knowledge acquisition is not a suitable approach to managing complex problems, a paradigm shift that would more fully open the door to the possibilities of adaptive management. Further progress would relate strongly to the willingness of program leaders and administrators to place trust and responsibility at more local organizational levels. There is nothing inherently wrong with a national or regional program, but it has to be flexible at the level at which problems are actually addressed on the ground (e.g., the level of BLM District Offices; Peterson et al. 2009). At present, managers can feel caught in a trap between planning strategy that is consistent with best available knowledge and the immediate need to satiate a public expectation of action or to meet legal obligations (e.g., National Environmental Policy Act) on critical issues (US Forest Service 2002). Similarly, public and institutional pressures can reinforce a reluctance to act among managers who are not comfortable with uncertainty in the relationship between current actions and desired future conditions (Ecological Society of America 2000). Therefore an institutionally based system of incentives and rewards for adaptive approaches to resource management will be critical for addressing complex problems on agency-controlled rangelands. Additionally, adaptive approaches to rangeland management are inherently nonspecific with respect to future management direction. Thus, a high degree of trust between implementing agencies and user groups is a prerequisite as discussed in the next section.

One of the greatest challenges for agency use of adaptive-style management is effectiveness monitoring. Monitoring effectiveness of all treatments in all areas over time is unrealistic given limited budget, personnel, and logistical resources. One alternative may be to tighten the linkage between management and research. Traditionally, scientists and managers tend to interact on a problem-by-problem basis, not the more continuous relationship needed to adaptively address complex problems (Fig. 2). Without a profitable linkage, the progress of management is bounded within the current state of our ecological knowledge, and the relevance of science is reduced.

We suggest that research could be used as a tool to test the assumptions of biological planning and evaluate competing management strategies. Under this scenario the effectiveness of specific management practices would be evaluated using smallscale research, and this work would then be scaled up to suggest effectiveness at larger scales. Research would have to be conducted on a variety of sites and over a time horizon sufficient to characterize temporal variability in response to treatments. An advantage of this approach is that it would promote an ongoing exchange of information as opposed to a point-in-time event ("New Model" in Fig. 2). To facilitate this process scientists may be able to take advantage of existing and proposed land management treatments at local scales. The forgoing scenario is not an across-the-board substitution for effectiveness monitoring, but it may represent the most reasonable alternative to point-based knowledge acquisition and provides a mechanism for iteratively linking what we do with what we know.

\section{Conservation Partner Ecosystems}

A second challenge to adaptive management is the necessity of management or conservation partnerships. For example, implementing the model in Figure 1 for landscape-level management of invasive annual grasses would require cooperation among a diverse set of stakeholders including those skilled in vegetation ecology, landscape ecology, grazing, fire, and geographic information systems, as well as interested user groups. Ultimately our ability to develop and leverage 

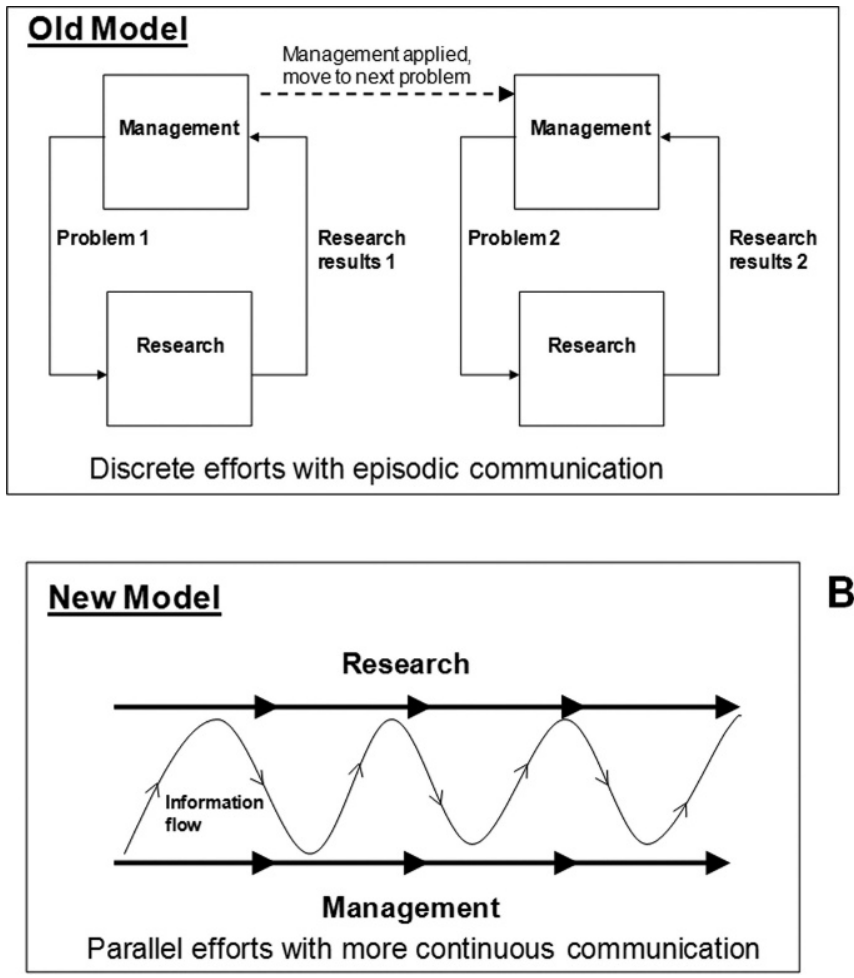

Figure 2. A, Management and science often interact on a problem-byproblem basis ("Old Model"). This relationship can provide tangible answers to simple problems, but does not lend itself to addressing complex problems, the nature of which vary in both space and time. $\mathbf{B}$, To address complex problems, science and management need to interact on a more continuous basis to iteratively refine both our knowledge of the ecology of the problem and the results of "on the ground" application of that knowledge ("New Model").

meaningful cross-professional partnerships depends on trust, and that trust is predicated on repeated, positive interactions. To be used to their maximum effectiveness, these relationships must represent an ongoing tradition of interaction as opposed to point-in-time events, which are less likely to cultivate meaningful levels of trust.

Some people would argue that we have now moved beyond the need for simple partnerships and into an era in which our conservation successes will depend on networks of partners that could be collectively considered as a "conservation partner ecosystem." In their recent book The Keystone Advantage, Iansiti and Levien (2004) applied the concept of a biological ecosystem to a variety of contemporary business ventures. Their work suggests that business success results not just from a company's core competencies, but also from its linkages to other ventures in the larger business community. This interdependency in turn creates a shared fate among these companies with respect to the health of their "business ecosystem."

Ultimately, if natural resources professionals are to be judged based on their ability to effectively deal with the major challenges of our time, they will certainly be collectively judged for handling issues relating to management of a growing list of complex rangeland problems (invasive species, threatened wildlife species, clean water, etc.). In our opinion a shared fate among the various players in rangeland conservation is real, and successful adaptive management of the broad-based and complex issues facing us today requires that we be wise stewards of our conservation partner ecosystems. Signs of good stewardship are in evidence. For example, the recent attention being given to sage-grouse in the western United States has spawned or is associated with a number of diverse partnerships, including a plethora of state and local working groups, the SAGEMAP project (http://sagemap.wr.usgs.gov), and the greater sage-grouse conservation assessment (Connelly et al. 2004).

One of the frequent realities of diverse partnerships is that a crisis is often required to initiate cooperation. However, when crises arise, an atmosphere of fear and opportunity can stand in the way of meaningful trust and dialogue. One way around this trap is to identify areas of common ground and make those areas the centerpiece of interaction between groups. A good example is the Blackfoot Challenge in Montana (www. blackfootchallenge.org). In this case, ranchers, environmentalists, nongovernmental organizations, communities, and a cadre of federal and state agencies all had a vested interest in conservation of the Blackfoot Valley. These interests were collectively tied to solving on-the-ground management problems in the form of unsustainable land use practices and commercial and private development. The various players embraced the shared fate of their interests and organized around the common vision of maintaining large intact landscapes and rural lifestyles. Efforts of partner organizations have paid large dividends in the form of perpetual conservation easements on over 43700 ha of land in the Blackfoot watershed (Ali Duvall, personal communication, April 2009). These easements will, by definition, preserve large portions of intact landscape that is not only aesthetically and culturally significant, but also maintains a variety of ecosystem services.

\section{Ecological Frameworks}

Research is often seen as a tool for solving management problems (Fig. 2A), but linkages between applied and theoretical science can be weak. The problem-solving focus of applied research has led to a plethora of published papers along the lines of treatment " $x$ " effects on ecological property " $y$ " within ecosystem system "z"; such work is, has been, and will continue to be invaluable in our efforts to impact the structure and function of rangeland ecosystems. However, if we are to be successful in using adaptive-style management approaches to address complex rangeland problems, our efforts must be set within the context of testable ecological theory that provides a framework for understanding root causes of system dynamics and fosters incremental learning.

Other sciences have followed such models to great success in tackling some of the most complex problems imaginable. Consider physics, for example. Newton first outlined a theoretical framework for gravitational force in 1687 (Newton 1999). This framework was used to ply the mysteries of the universe for the next two centuries and created a platform of understanding that helped Einstein to redefine our perceptions of space and time in the early 1900s (Einstein 1921; Penrose 2006). A current focus of physics is to unite the ideological framework of Einstein with that of quantum physics (which applies to subatomic scales) to produce a unified "Theory of Everything" (Maddox 1999; Weinberg 1999). The strength of these frameworks lies not necessarily in their accuracy, but 
Table 1. Ecologically based framework for use in understanding rangeland plant succession including causes of succession, driving processes, and modifying factors (adapted from Krueger-Mangold et al. 2006).

\begin{tabular}{lll}
\hline Causes of succession & Contributing process & \multicolumn{1}{c}{ Modifying factor } \\
\hline Site availability & Disturbance & Size, severity, time intervals, patchiness, predisturbance history \\
Species availability & Dispersal & Dispersal mechanisms and landscape features \\
& Propagule pool & Land use, disturbance interval, species life history \\
Species performance & Resource supply & Soil, topography, climate, site history, microbes, litter retention \\
& Ecophysiology & Germination requirements, assimilation rates, growth rates, genetic differentiation \\
& Life history & Allocation, reproduction timing and degree \\
& Stress & Climate, site-history, prior occupants, herbivory, natural enemies \\
& Interference & Competition, herbivory, allelopathy, resource availability, predators \\
\hline
\end{tabular}

instead in their role as an organizing point, around which scientific advancement evolves through both validation and constructive dissention.

According to the Merriam-Webster Online Dictionary, a "framework" is a basic conceptual structure (as of ideas). In rangeland ecology, we must deal with enormous spatial and temporal variability and are unlikely to have the unified Theory of Everything that may be possible in physics. An example of an ecological framework is the state-and-transition model (STM) approach to describing rangeland vegetation dynamics. Prior models based on simple linear succession (Clements 1936; Weaver and Clements 1938; Dyksterhuis 1949) did not provide a broad enough framework for many rangeland settings. Using the sagebrush steppe as an example, there can be transitions to annual grass dominance or western juniper dominance, and intact plant communities can be described in the context of the historical fire cycle. There are many potential states and a variety of factors that can cause transition between states. Thus, the STM approach initially described by Westoby et al. (1989) is a better framework for rangelands that do not follow the linear succession model (see also Briske et al. 2008; Bestelmeyer et al. 2009). The STM approach can be very useful for integrating expert knowledge, literature, and field observations (Bestelmeyer et al. 2009) and for organizing what we think we know about a particular ecological site. However, the STM approach does not have predictive capability (i.e., transitions to alternate states describe a change but do not necessarily provide the mechanism). A transition might be caused by grazing, climate, fire, or species invasions, but we would have to speculate on the ecological mechanism (competition, change in resource availability, presence of new propagules, etc.; Table 1).

A second framework based on the causes of succession has been proposed as a means of identifying the management actions necessary to cause a successional change or transition (Sheley et al. 1996; Krueger-Mangold et al. 2006; Sheley et al. 2006). The three primary causes of succession (site availability, species availability, and species performance; Table 1) are evaluated for each desired successional change (e.g., changing from annual invasive to perennial species). This second framework allows a mechanistic evaluation of the factors controlling species change. For example, if an invasive species has become a problem, could a particular weather pattern be causing this species to be increasingly competitive? Are there sufficient propagules to restore desirable species if conditions change, or control practices are applied? Do we need to create a disturbance so desirable species have safe sites for establishment? This successional management framework allows us to integrate virtually all of our rules associated with species changes. Sheley et al. (2009) found that in two of three cases using the successional management framework improved decision making about treatment combinations needed to maximize rangeland seedling establishment.

Adherence to ecological frameworks may also help managers to identify the most effective conceptual scale at which to address complex problems. Consider the growing list of imperiled or sensitive sagebrush-associated wildlife species (Rowland and Wisdom 2002) that are demanding increased attention from land management entities. This "focus on the pieces" belies the fact that ecosystems themselves are driven by fundamental biotic and abiotic processes and that these individual wildlife species don't control the "health" of the overall system, they respond to it. In turn, influencing fundamental processes may provide an elegant mechanism for affecting the complex overall system and its constituent species. For example, interrupted fire cycles in mountain big sagebrush (Artemisia tridentata subsp. vaseyana $\mathrm{Rydb}$ ) communities have favored performance of western juniper (Juniperus occidentalis Hook.) and disfavored performance of sagebrush and bunchgrasses, leading to increased juniper dominance and a decline in habitat for a variety of wildlife species (Clements and Young 1997; Miller and Eddleman 2000; Reinkensmeyer et al. 2007). Rather than direct management on the basis of individual wildlife species, a more economical approach would be to take actions to restore the fire cycle. Specific management tactics in support of that strategy would vary over space and time but could take the form of active management (e.g., prescribed fire) or more passive actions such as alteration of wildland fire suppression policies (National Interagency Fire Center 2009). ${ }^{1}$ Some may consider this system-level approach to be an overly simplistic vision for managing sensitive wildlife species (see Palmer et al. 1997); however, it represents both an effective starting point for an ecologically based adaptive management program and can generate testable hypotheses.

\section{Rangeland Management in Space and Time}

A good framework and a keen understanding of the ecological processes underlying a complex problem do not necessarily translate into "on the ground" solutions, and even when they

${ }^{1}$ Fire may have negative impacts in areas where annual grass invasion is an issue, which highlights the spatial complexity of rangelands. 

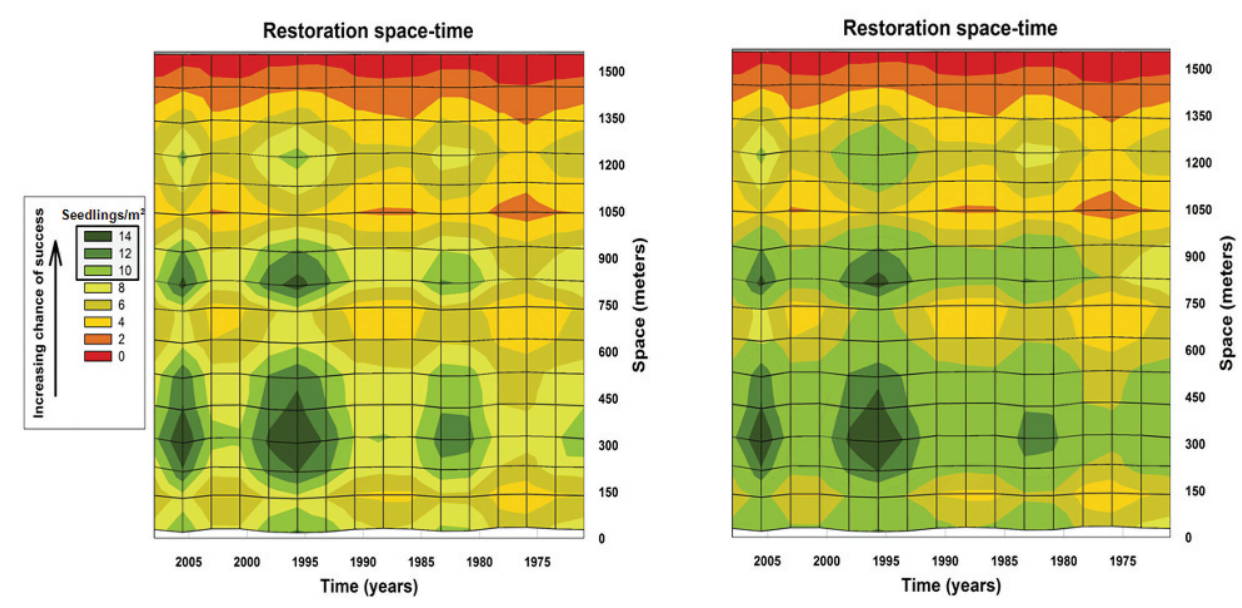

Figure 3. A, The anatomy of a complex problem illustrated by depicting hypothetical windows of management opportunity in space and time for restoring annual grass-infested sagebrush steppe rangeland. These data indicate predicted density of seeded perennial bunchgrasses. Green-shaded areas depict windows of opportunity that occur when conditions in both space and time allow for acceptable levels of restoration success (in this case $\geq 10$ seedlings $\cdot \mathrm{m}^{-2}$ ); nongreen areas are outside this window. The "Space" axis suggests that site conditions necessary for germination and establishment of desired species vary as we travel across the landscape, and at a given point on the landscape, chances of success vary over "Time." In our hypothetical example, opportunities are most limited in space by excess nitrogen (which reduces competitive fitness of native perennials) and in time by insufficient soil moisture for germination. B, Windows of management opportunity have been increased with the application of a cover crop of sterile rye (decreases soil nitrogen) and a hydrophilic seed coating for native perennial grass seeds (increases effective moisture in vicinity of the seed) without altering the definition of restoration success.

do, the spatial/temporal applicability of such "solutions" may be limited. For a framework to be useful in addressing complex problems, we have to be able to translate knowledge of ecological processes into management options in a way that accounts for barriers to management in both space and time (Thompson et al. 2001). For example, the conceptualization presented in Figure 3A provides a glimpse into the hypothetical position and extent of management opportunity in space and time for sagebrush steppe range restoration and suggests that such opportunities will be limited because of oscillations in site and climatic factors. However, the windows of management opportunity implied in Figure 3A are rather small, which begs the question of whether management would be saddled with limited opportunities for restoration, or whether those windows of opportunity could be expanded.

When faced with limited management opportunities, one way to think about the task at hand is to identify practices that allow us to shift the ecological space-time relationship in favor of increased restoration success. Shifting the ecological spacetime relationship would be predicated on a process-based knowledge of the system and would take the form of specific treatments aimed at modifying the ecological factors thought to be limiting the chances of restoration success in space and time. Applying the ecological framework of Krueger-Mangold et al. (2006, Table 1) to Figure 3A, we might hypothesize that a lack of success in restoring native perennial grasses is being caused by deficiencies in species performance via the process of resource supply; specifically, excess nitrogen (which favors annual grasses) in space and insufficient precipitation for germination of perennial grass seeds in time. Management, in turn, could respond by incorporating a cover crop of sterile rye and hydrophilic seed coating for seeded native perennial grasses into their restoration strategy. The cover crop would help to decrease soil nitrogen (Herron et al. 2001), while a seed coating could decrease the soil water content needed to stimulate germination (Fig. 3B). Thus the goal is to maximize windows of management opportunity by using practices that shift the ecological space-time relationship without altering our definition of success. The utility of this general approach is that it links process-based ecology to on-the-ground resource issues using a testable model that incorporates both space and time and is adaptable to changes in limiting factors/processes. In rangeland ecosystems, where climatic variables (Hardegree and Van Vactor 2004) are often a significant limiting factor, the "time" portion of the ecological space/time continuum should be considered as a central challenge to effective restoration.

\section{MANAGING EXPECTATIONS}

The decision to use annual grasses in the model for Figure 3 was, in large part, due to the fact that they are a convenient example of the nuances and challenges involved in addressing complex problems. In truth, management of rangelands involves a wealth of such issues. Whether it be modern-day livestock grazing management (Miller et al. 1994), fire impacts (Miller and Eddleman 2000), or the seemingly all encompassing issue of wildlife species such as sage-grouse (Connelly et al. 2004; Crawford et al. 2004), natural resource professionals are expected to develop comprehensive solutions to increasingly complex problems. Furthermore, these solutions need to be adaptive as the problems continue to evolve over space and time. With this in mind, a reasonable question to ask is this: How successful can we expect to be? 
Successfully matching our expectations with our technical aptitude and logistical capabilities will strongly influence our ability to accomplish management objectives. In some cases this will involve difficult decisions: reducing resources spent on seemingly intractable problems in favor of spending those resources on problems with a higher potential for success. These decisions may also relate to our ability to monitor progress toward stated objectives, because simply acting on an issue can be problematic without the proper tools for monitoring progress (Fig. 1). Developing some means of separating management impacts from background variation is critical. Controls (i.e., untreated areas) or a mechanistic model will be necessary for separating responses to extrinsic factors from those associated with management. The important point, though, is to discuss expectations within the partner network to ensure a common direction. Well-documented case studies may be helpful to this discussion in that models for addressing complex problems in one system may suggest productive approaches for other systems (Bradbury 2000).

Another approach to managing expectations would be to step backward to a more manageable conceptual level, and then scale our expectations accordingly. An approach of this sort would be similar to that outlined by Hollick (1993), where he described environmental management in terms of selforganizing systems. Under the paradigm of self-organizing systems, the environment is under constant pressure to change as the result of a complex mix of interacting factors that vary over both space and time. The job of the environmental manager is to define the range of acceptable conditions for the system and, when necessary, implement the simplest set of management actions necessary to keep the system within desired bounds. Thus expectations now relate to a range of possible outcomes as opposed to a specific idealized end-point. Selecting the appropriate bounds will be influenced by the desired resource conditions, logistical and technical capabilities, and knowledge of proximity to thresholds for alternative plant communities (i.e., resilience; see Briske et al. 2008). In a sense, this style of environmental management is similar to sailing a boat, where the objective is to maintain a general course (i.e., synonymous with trajectory of the environmental system) by making corrections of the appropriate magnitude in time and space. This approach dovetails well with adaptivestyle conservation in that it relies on a feedback system that iteratively links management direction with changing condition of the resource. Defining and implementing the most effective set of management actions to keep the environmental system in bounds will rely strongly on a process-based knowledge of the underlying ecology and the ability to recognize and act on windows of opportunity in both space and time (Fig. 3).

\section{A FINAL THOUGHT}

Perhaps our biggest challenge in addressing complex rangeland problems is also our greatest asset, that is, the driving need to provide a definite solution to a tangible problem. That desire has long been associated with advancing our society and has produced many notable successes, ranging from cures for infectious disease to driving golf balls on the moon. The idea of finding "solutions" in the form of an approach (e.g., adaptive management) can run counter to both societal expectations and our vision as scientists and managers. We want the answer and want it now! However, when it comes to complex rangeland problems, addressing the expectations of society and honoring our own commitment to professional excellence may be an endeavor best spawned by humility, fed with curiosity, and sustained through determination. In fact, complex problems are never really solved in the conventional sense, and when they are, we just might have a problem.

\section{MANAGEMENT IMPLICATIONS}

From a management standpoint, the most important points of this paper are to promote recognition of the dichotomy between simple and complex problems, and the idea that static management in the face of a dynamic problem will not yield the most favorable results. That said, it should be stressed that not all problems are complex and in some instances problems may contain both simple and complex elements. For example, Miller et al. (2000) found that loss of the herbaceous understory with encroaching juniper varied strongly based on site characteristics, whereas the understory shrub component was generally lost when juniper abundance crossed an upper threshold, regardless of site conditions. Assessing juniper encroachment impacts on shrub cover is a relatively simple issue, whereas the impact on herbaceous cover is more complex.

Certainly most researchers and managers in the natural resource arena understand that the ecosystems they work with are variable in space and time. We suggest though that more thought should be given to the nature of the problems we are addressing and the robustness of our assumptions. It has been surprising to us how often the general notions and "common knowledge" we cling to are either unsubstantiated or simply wrong.

\section{ACKNOWLEDGMENTS}

Ultimately an opinion-based paper is not just the summation of independent thought, but is also a collective product shaped by both scholarly and informal interactions with a multitude of colleagues. We are particularly indebted to the late Dr Charles Baxter for his words and wisdom regarding management of large-scale natural resources issues. We also thank Editor Dave Briske, Associate Editor Leigh Hunt, and five reviewers for their helpful comments and suggestions.

\section{LITERATURE CITED}

Anonymous. 1936. The western range Senate document No.199. 74th Congress, 2nd Session. Washington, DC, USA: Government Publishing Office. 620 p.

Bestelmeyer, B. T., A. J. Tugel, G. L. Peacock, Jr., D. G. Robinett, P. L. Shaver, J. R. Brown, J. E. Herrick, H. Sanchez, and K. M. Havstad. 2009. State-andtransition models for heterogeneous landscapes: a strategy for development and application. Rangeland Ecology and Management 62:1-15.

Bradbury, R. H. 2000. Futures, prediction and other foolishness. Plenary address to the Conference of the International Society of Ecological Economics; 8 July 2000; Canberra, Australia.

Briske, D. D., B. T. Bestelmeyer, T. K. Stringham, and P. L. Shaver. 2008. Recommendations for development of resilience-based state-and-transition models. Rangeland Ecology and Management 61:359-367. 
Clements, C. D., And J. A. Young. 1997. A viewpoint: rangeland health and mule deer habitat. Journal of Range Management 50:129-136.

Clements, F. E. 1936. Nature and structure of the climax. Journal of Ecology 24:252-284.

Coluins, J. 2001. Good to great: why some companies make the leap ... and others don't. New York, NY, USA: HarperCollins. 300 p.

Connelly, J. W., S. T. Knick, M. A. Schroeder, and S. J. Stiver. 2004. Conservation assessment of greater sage-grouse and sagebrush habitats. Unpublished report. Cheyenne, WY, USA: Western Association of Fish and Wildlife Agencies.

Crawford, J. A., R. A. Olson, N. E. West, J. C. Mosley, M. A. Schroeder, T. D. Whitson, R. F. Miller, M. A. GregG, and C. S. Boyd. 2004. Invited synthesis paper: ecology and management of sage-grouse and sage-grouse habitat. Journal of Range Management 57:2-10.

Dyksterhuis, E. J. 1949. Condition and management of rangeland based on quantitative ecology. Journal of Range Management 2:104-115.

ECOLOGICAL SocietY OF America. 2000. Applying ecological principles to management of the U.S. national forests. Issues in Ecology, No. 6. Washington, DC, USA: ESA. $21 p$.

EINSTEIN, A. 1921. Relativity: the special and general theory. Translated by R. W. Lawson. New York, NY, USA: Henry Holt. 168 p.

EISWERTH, M. E., AND J. S. SHonkWILER. 2006. Examining post-wildfire reseeding on arid rangeland: a multivariate tobit modelling approach. Ecological Modelling 192:286-298.

Government Accountability Office. 2006. Wildland fire rehabilitation and restoration: Forest Service and BLM could benefit from improved information on status of needed work. GA0-06-670. Washington, DC, USA: Government Printing Office. $44 \mathrm{p}$.

Hardegree, S. P., and S. S. Van Vactor. 2004. Microclimatic constraints and revegetation planning in a variable environment. Weed Technology 18:1213-1215.

Herron, G. J., R. L. Sheley, B. D. Maxwell, and J. S. Jacobsen. 2001. Influence of nutrient availability on the interaction between spotted knapweed and bluebunch wheatgrass. Restoration Ecology 9:326-331.

Holııck, M. 1993. Self-organizing systems and environmental management. Environmental Management 17:621-628.

HoluING, C. S. 1978. Adaptive environmental assessment and management. London, United Kingdom: John Wiley and Sons. 398 p.

HuLL, A. C. 1974. Species for seeding arid rangeland in southern Idaho. Journal of Range Management 27:216-218.

IANSITI, M., AND R. LEVIEN. 2004. The keystone advantage: what the new dynamics of business ecosystems mean for strategy, innovation, and sustainability. Cambridge, MA, USA: Harvard Business School Press. 304 p.

Knutson, K. C., D. A. Pyke, T. A. Wirth, D. S. Pilliod, M. L. Brooks, and J. C. Chambers. 2009. A chronosequence feasibility assessment of emergency fire rehabilitation records within the intermountain western United States: final report to the Joint Fire Science Program. Project 08-S-08: U.S. Geological Survey Open-File Report 2009-1099. 20 p. Available at: http://store.usgs.gov. Accessed 2 October 2009.

Krueger-Mangold, J. M., R. L. Sheley, and T. J. Svejcar. 2006. Toward ecologicallybased invasive plant management on rangeland. Weed Science 54:597-605.

Lysne, C. R., AND M. Pellant. 2004. Establishment of aerially seeded big sagebrush following southern Idaho wildfires. Technical Bulletin 2004-01. Boise, ID, USA: Department of the Interior, Bureau of Land Management. $14 \mathrm{p}$.

Maddox, J. 1999. The unexpected science to come. Scientific American 281:62-67.

Mann, C. C., And M. L. Plummer. 1996. Noah's choice: the future of the Endangered Species Act. New York, NY, USA: Alfred Knopf. 302 p.

Millek, R. F., And L. L. EddLeman. 2000. Spatial and temporal changes of sage grouse habitat in the sagebrush biome. Oregon Agricultural Experiment Station Bulletin 151. Corvallis, OR, USA: Oregon Agricultural Experiment Station. 39 p.

Miller, R. F., R. J. SveJcAR, And J. A. Rose. 2000. Impacts of western juniper on plant community composition and structure. Journal of Range Management 53:574-585.

Miller, R. F., T. J. Svejcar, And N. E. West. 1994. Implications of livestock grazing in the Intermountain sagebrush region: plant composition. In: M. Vavra, W. A.
Laycock, and R. D. Pieper [EDS.]. Ecological implications of livestock herbivory in the west. Denver, C0, USA: Society for Range Management. p. 101-146.

National Ecological Assessment Team. 2006. Strategic habitat conservation: final report of the National Ecological Assessment Team. Submitted to the Regional Directors of the U.S. Fish and Wildlife Service and the U.S. Geological Survey. $34 \mathrm{p}$.

National Interagency Fire Center. 2009. Wildlife fire use: managing for a fire-smart landscape. Fire Science Digest, Issue 4, January. Boise, ID, USA: NIFC. 12 p.

Newton, I. 1999. The Principia: mathematical principles of natural philosophy. Translated by I. B. Cohen and A. Whitman. Berkeley, CA, USA: University of California Press. 974 p.

Palmer, M. A., R. F. Ambrose, and N. L. Poff. 1997. Ecological theory and community restoration ecology. Restoration Ecology 5:291-300.

Penrose, R. 2006. What is reality? New Scientist 192:31-39.

Peterson, D. L., J. K. Agee, G. H. Aplet, D. P. Dykstra, R. T. Graham, J. F. Lehmkuhl, D. S. Pilloid, D. F. Potts, R. F. Powers, and J. D. Stuart. 2009. Effects of timber harvest following wildfire in western North America. Gen. Tech. Rep. PNWGTR-776. Portland, OR, USA: US Department of Agriculture, Forest Service, Pacific Northwest Research Station. $51 \mathrm{p}$.

Pyke, D. A., T. 0. McArthur, K. S. Harrison, and M. Pellant. 2003. Coordinated intermountain restoration project-fire, decomposition and restoration. In: N. Allsopp, A. R. Palmer, S. J. Milton, K. P. Kirkman, G. I. H. Kerley, C. R. Hurt, and C. J. Brown [EDS.]. Proceedings of the VIlth International Rangelands Congress; 26 July-1 August 2003; Durban, South Africa. p. 116-124.

Reever-Morghan, K. J., R. L. Sheley, and T. J. Svejcar. 2006. Successful adaptive management: the integration of research and management. Rangeland Ecology and Management 59:216-219.

Reinkensmeyer, D. P., R. F. Miller, R. G. Anthony, and V. E. Marr. 2007. Avian community structure along a mountain big sagebrush successional gradient. Journal of Wildlife Management 71:1057-1066.

Richards, R. T., J. C. Chambers, and C. Ross. 1998. Use of native plants on federal lands: policy and practice. Journal of Range Management 51:625-632.

Rowland, M. M., AND M. J. WISDOM. 2002. Research and problem analysis for greater sagegrouse in Oregon. US Department of Agriculture, Forest Service, Pacific Northwest Research Station. Final report. La Grande, OR, USA: Government Printing Office. 75 p.

Schreiber, E. S. G., A. R. Bearlin, J. Nicol, and C. R. Todd. 2004. Adaptive management: a synthesis of current understanding and effective application. Ecological Management and Restoration 5:177-182.

Sheley, R. L., J. J. James, And E. C. BARD. 2009. Augmentative restoration: repairing damaged ecological processes during restoration of heterogeneous environments. Invasive Plant Science and Management 2:10-21.

Sheley, R. L., J. M. Mangold, and J. L. Anderson. 2006. Potential for successional theory to guide restoration of invasive-plant-dominated rangeland. Ecological Monographs 76:365-379.

Sheley, R. L., T. J. SvejCar, And B. D. Maxwell. 1996. A theoretical framework for developing successional weed management strategies on rangeland. Weed Technology 10:766-773.

Thompson, J. N., O. J. Reichman, P. J. Morin, G. A. Polis, M. E. Power, R. W. Sterner, C. A. Couch, L. Gough, R. Hold, D. U. Hooper, F. Keesing, C. R. Lovell, B. T. Milne, M. C. Molles, D. W. Roberts, and S. Y. Strauss. 2001. Frontiers of ecology. Bioscience 51:15-24.

Trefethen, J. B. 1985. An American crusade for wildlife. Alexandria, VA, USA: Boone and Crockett Club. 409 p.

United States Forest Service. 2002. The process predicament: how statutory, regulatory, and administrative factors affect national forest management. Washington, DC, USA: Government Printing Office. Available at: http://www.fs. fed.us/projects/documents/Process-Predicament.pdf

Weaver, J. E., and F. E. Clements. 1938. Plant ecology. New York, NY, USA: McGraw-Hill. $601 \mathrm{p}$.

WeInBerg, S. 1999. A unified physics by 2050? Scientific American 281:68-75.

Westoby, M., B. Walker, and I. Noy-MeiR. 1989. Opportunistic management for rangelands not at equilibrium. Journal of Range Management 42:266-274.

Whaley, R. S. 1993. Working partnerships: elements for success. Journal of Forestry 91:10-11. 